\title{
Thermal comfort conditions and Polish legal requirements regarding temperatures in residential rooms
}

\author{
Muniak Damian ${ }^{1, *}$ \\ ${ }^{1}$ Cracow University of Technology, ul. Jana Pawła II 37, 31-864 Kraków, Poland
}

\begin{abstract}
The article discusses the parameters of thermal comfort in residential environments. The analysis is referred to the Polish legal requirements, pointing out the differences between them and some of their effects, both from the ergonomic, and economic points of view.
\end{abstract}

\section{Introduction}

Conditions of thermal comfort in residential environments should be ensured in both the heating season, when the building must be heated and in the summer, when it often requires cooling. These needs are the consequence of climatic conditions. Moreover, the obligation of application installation or heating devices results directly from the provisions of Polish Construction Law [1]. In one of its implementing acts, Regulation of the Minister of Infrastructure of 12 April 2002 on the technical conditions to be met by buildings and their location, Dz.U. (Journal of Laws) 02.75.690 as amended (in Polish: Rozporządzenie Ministra Infrastruktury z dnia 12 kwietnia 2002 roku w sprawie warunków technicznych, jakim powinny odpowiadać budynki i ich usytuowanie, Dz.U.02.75.690 z późniejszymi zmianami) [2], in paragraph $§ 132.1$, it is said that: "the building, which due to its destination requires heating, should be equipped with the heating system or other appliances heating systems, other than furnaces, fireplaces or kitchen shafts."

\section{Thermal comfort}

The basic aim of any building heating installation is to ensure appropriate temperature conditions for the people in it. The temperature conditions are a component of what is referred to as thermal comfort, which, in turn, affects the room microclimate, i.e. the set of a given room all physical and chemical parameters that have an impact on the human organism. Some of these parameters, such as the air pressure and ionization, the noise level, lighting, the concentration of carbon dioxide or air pollutants, are not directly related to the heating installation operation. Therefore, analysing the performance of such a system, the considerations come down to an analysis of a narrower issue - the thermal comfort conditions.

The operation of radiators in a given room has both a direct and indirect impact on thermal comfort parameters. For example, the temperature values of air, partitions and elements of the room equipment are affected directly. The radiator operation indirect impact is visible for example in the case of the relative and absolute values of humidity, the air flow velocity and circulation in a given zone.

In order to compare indoor environments characterized by a different combination of parameters that affect thermal comfort, an appropriate comparative criterion has to be used. Many such criteria and methods of their evaluation have been developed over the years. Depending on the region, some of them are more popular than others. It is believed that the first researchers who focused on the issue of determining the thermal comfort parameters were Englishmen Sheppard and Hill [3]. In 1913 they proposed mathematical formulae between the values of temperature and relative humidity, which provide a comfortable environment for people. One of the first widespread parameters was the effective temperature (ET) introduced in the USA in the 1920's by Yaglou et al. [4]. More research was done in the field in the next few years and new more reliable parameters were put forward, including the new (modified) effective temperature $\mathrm{ET}^{*}$ [5] and the standard effective temperature (SET) $[5,6,7]$ The ET index defines the combination of the air temperature and relative humidity at the level of $100 \%$, which causes the same thermal sensation as a combination of a real environment temperature and humidity assuming an identical air flow velocity $[8,7]$. ET* defines the temperature of a temperature-homogeneous black environment with a $50 \%$ relative humidity of motionless air $(\mathrm{w}<0.1 \mathrm{~m} / \mathrm{s})$ for which a given person experiences the same thermal and thermoregulation load as that occurring under real conditions, at identical values of parameters met, clo [8, 5]. SET, the parameter currently used by the ASHRAE (American Society of Heating, Refrigerating and Airconditioning Engineers) [9], defines the temperature of a temperature-homogeneous black environment with a $50 \%$ relative humidity of motionless air $(\mathrm{w}<0.1 \mathrm{~m} / \mathrm{s})$ for which a given person, compared to standard parameters

* Corresponding author: damian.muniak@gmail.com 
of a given physical activity (e.g. met $=1.0 \div 1.1$ and clo=0.6), experiences the same thermal and thermoregulation load (skin temperature, sweating) as that occurring under real conditions (real values of met and clo) $[9,8,10,11,6,7,12]$. The methodology of the SET parameter calculation is laid out in the ASHRAE Standard 55-2013 [9]. In the first half of the twentieth century, there were also published extensive monographs on thermal comfort. The author of one of the first was a Polish internist, Nowakowski, who published his work in 1935 [13].

In order to assess the temperature felt by a human in a given room, the temperature of air, partitions and equipment of the room (the radiant temperature) all have to be taken into consideration. The resultant value is referred to as the operative temperature or operating temperature. Different methods of the quantity determination have been developed and proposed over the years. The manner in which it is currently calculated is regulated by the ISO 7726 international standard [13]. According to it, the parameter should be calculated using the following formula:

$$
t_{\mathrm{oper}}=\frac{\alpha_{\mathrm{k}} \cdot t_{\mathrm{k}}+\bar{\alpha}_{\mathrm{pr}} \cdot \bar{t}_{\mathrm{pr}}}{\alpha_{\mathrm{k}}+\bar{\alpha}_{\mathrm{pr}}} .
$$

The standard also lays out the methodology of determination of the formula individual elements.

The operative temperature is the temperature of a temperature-homogenous black environment (in terms of the heat transfer) where a human, due to radiation and convection, exchanges the same amount of heat as in a comparable temperature-heterogeneous real environment $[14,15]$. If the difference between the temperature individual values is smaller than $4 \mathrm{oC}$, it may be calculated, with a certain approximation, as the mean arithmetic value of the air and radiant temperatures, ignoring individual surface film conductance coefficients [16]. The temperature sensation is thus affected by both the air temperature and the temperature of surrounding partitions and equipment.

However, using operative temperature as the only index of thermal comfort evaluation may in some situations prove insufficient because the thermal comfort sensation is also affected by individual parameters, unrelated to a given environment.

Thermal comfort is defined as a state in which a given environment, such as a room for example, is neutral in its effect on the thermal sensation of a human. This means that neither locally, on some body parts, nor globally does the person feel too high or too low a temperature. This particular state is achieved for the human body thermal balance and may be described as follows $[17,18,19]$ :

$$
\begin{aligned}
& \dot{M}-\dot{W}=\left(\dot{q}_{\text {konw }}+\dot{q}_{\mathrm{pr}}+\dot{q}_{\mathrm{pot}}\right)+ \\
& \left(\dot{q}_{\text {odd,konw }}+\dot{q}_{\text {odd,par }}\right)+\left(\dot{q}_{\mathrm{ak}, \mathrm{sk}}+\dot{q}_{\mathrm{ak}, \mathrm{org}}\right)
\end{aligned}
$$

$$
\begin{aligned}
& \dot{M}-\dot{W}>\left(\dot{q}_{\text {konw }}+\dot{q}_{\text {pr }}+\dot{q}_{\text {pot }}\right)+\left(\dot{q}_{\text {odd, konw }}+\dot{q}_{\text {odd, par }}\right)+ \\
& +\left(\dot{q}_{\text {ak,sk }}+\dot{q}_{\text {ak, org }}\right)
\end{aligned}
$$

then there is an increment in the energy accumulated in the human body and the temperature rises. The human feels warmth.

If:

$$
\begin{aligned}
& \dot{M}-\dot{W}<\left(\dot{q}_{\text {konw }}+\dot{q}_{\mathrm{pr}}+\dot{q}_{\mathrm{pot}}\right)+\left(\dot{q}_{\mathrm{odd}, \mathrm{konw}}+\dot{q}_{\mathrm{odd}, \mathrm{par}}\right)+ \\
& +\left(\dot{q}_{\mathrm{ak}, \mathrm{sk}}+\dot{q}_{\mathrm{ak}, \mathrm{org}}\right)
\end{aligned}
$$

then there is a decrease in the energy accumulated in the human body and the temperature drops. The human feels cold.

As the equation above indicates, due to metabolism the organism produces energy, thus building up the body temperature, and gives up energy through convection and radiation from the skin surface, sweat evaporation, breathing and performing work. The human warmblooded organism strives to maintain a certain temperature value which, however, may change in a certain range depending on a number of factors (excluding diseases). The body thermoregulation system is responsible for keeping the range of these changes within certain boundaries. For example, if the temperature needs to be reduced, the system triggers the sweating process. Evaporating from the skin surface, sweat absorbs the skin evaporation heat and lowers the temperature. If heat losses need to be reduced, the thermoregulation system may restrict peripheral circulation, thus diminishing the drop in the blood temperature. A physical effort always involves a rise in the energy produced by the organism, and the thermoregulation system activates mechanisms aiming at a reduction in temperature.

The heat output $\dot{M}$ produced by the organism due to metabolism depends on the type of activity and is proportional to the volume of inhaled air, i.e. to the intensity of breathing. This parameter varies in a wide range. For example, for a sitting person who is not performing any physical work it is assumed at the level of $58 \mathrm{~W}$ per $1 \mathrm{~m}^{2}$ of the skin surface area. The parameter related to energy generation due to metabolism is expressed in metabolic units met, and 1 met $=58 \mathrm{~W} / \mathrm{m}^{2}$.

Parameter $\dot{W}$ represents the heat output converted to mechanical work and not accumulated in the body. For this case the value is close to zero. As physical activity becomes more intensive, the heat output resulting from metabolism rises and so does the amount of accumulated energy because not all of it is converted to work. In the case of hard physical labour or for some sports, the metabolic rate may exceed $1000 \mathrm{~W} / \mathrm{m}^{2}$. The values of the parameter for different activities may be found for example in $[17,18,15]$. The most common values are listed in table 1.

If: 
Tab. 1. Metabolic rates [15]

\begin{tabular}{|l|c|c|}
\hline \multirow{2}{*}{ Activity } & \multicolumn{2}{|c|}{ Metabolic rate } \\
\cline { 2 - 3 } & $\mathbf{W} / \mathbf{m}^{2}$ & met \\
\hline Reclining & 46 & 0,8 \\
\hline Seatem, relaxed & 58 & 1,0 \\
\hline Sedentary activity (office, dwelling, & 70 & 1,2 \\
school, laboratory) & & \\
\hline Standing, light activity (shopping, & 93 & 1,6 \\
laboratory, light industry) & & \\
\hline Standing, medium activity (shop & 116 & 2,0 \\
assistant, domestic work, machine work) & & \\
\hline Walking on level ground: & & \\
2 km/h & 110 & 1,9 \\
$3 \mathrm{~km} / \mathrm{h}$ & 140 & 2,4 \\
$4 \mathrm{~km} / \mathrm{h}$ & 165 & 2,8 \\
$5 \mathrm{~km} / \mathrm{h}$ (typical walk) & 200 & 3,4 \\
\hline
\end{tabular}

The amount of heat given up to the environment is also affected by clothing. The higher the clothing heat resistance, the more heat may be accumulated in the body, and the body temperature may rise. In order to determine the impact of clothing on the thermal comfort sensation, the clo (clothing) parameter is introduced [20], which defines the model heat resistance of clothing $\left(1 \mathrm{clo}=0.155\left(\mathrm{~m}^{2} \mathrm{~K}\right) / \mathrm{W}\right)$. Calculating the heat resistance value and the clo parameter, the heat resistance values of individual items of clothing have to be summed up. A list of values of these parameters may be found for example in $[17,18,15]$. The most common values are listed in table 2 .

Tab. 2. Thermal insulation for typical combinations of garments [15]

\begin{tabular}{|c|c|c|}
\hline Work clothing & \multicolumn{2}{|c|}{$\boldsymbol{R}_{\mathbf{c l}}$} \\
\cline { 2 - 3 }$\left(\mathbf{m}^{\mathbf{2}} \mathbf{K}\right) / \mathbf{W}$ \\
\hline $\begin{array}{c}\text { Underpants, boiler suit, socks, } \\
\text { shoes }\end{array}$ & 0,7 & 0,110 \\
\hline $\begin{array}{c}\text { Underpants, shirt, boiler suit, } \\
\text { socks, shoes }\end{array}$ & 0,8 & 0,125 \\
\hline $\begin{array}{c}\text { Underpants, shirt, trousers, } \\
\text { smock, socks, shoes }\end{array}$ & 0,9 & 0,140 \\
\hline $\begin{array}{c}\text { Underwear with short sleeves } \\
\text { and legs, shirt, trousers, } \\
\text { jacket, socks, shoes }\end{array}$ & 1,0 & 0,155 \\
\hline $\begin{array}{c}\text { Underwear with long legs and } \\
\text { sleeves, thermo-jacket, socks, } \\
\text { shoes }\end{array}$ & 1,2 & 0,185 \\
\hline $\begin{array}{c}\text { Underwear with short sleeves } \\
\text { and legs, shirt, trousers, } \\
\text { jacket, heavy quilted outer } \\
\text { jacket and overalls, socks, } \\
\text { shoes, cap, gloves }\end{array}$ & 1,4 & 0,220 \\
\hline $\begin{array}{c}\text { Underwear with short sleeves } \\
\text { and legs, shirt, trousers, } \\
\text { jacket, heavy quilted outer } \\
\text { jacket and overalls, socks, } \\
\text { shoes }\end{array}$ & 2,0 & 0,310 \\
\hline $\begin{array}{c}\text { Underwear with long sleeves } \\
\text { and legs, thermo-jacket and } \\
\text { trousers, Parka with heavy } \\
\text { quitting, overalls with heave } \\
\text { quilting, socks, shoes, cap, } \\
\text { gloves }\end{array}$ & 2,55 & 0,395 \\
\hline
\end{tabular}

\begin{tabular}{|c|c|c|}
\hline \multirow{2}{*}{ Daily wear clothing } & \multicolumn{2}{|c|}{$\boldsymbol{R}_{\mathbf{c l}}$} \\
\cline { 2 - 3 }$\left(\mathbf{m}^{\mathbf{2}} \mathbf{K}\right) / \mathbf{W}$ \\
\hline $\begin{array}{c}\text { Panties, T-shirt, shorts, light } \\
\text { socks, sandals }\end{array}$ & 0,3 & 0,050 \\
\hline $\begin{array}{c}\text { Underpants, shirt with short } \\
\text { sleeves, light trousers, light } \\
\text { socks, shoes }\end{array}$ & 0,5 & 0,080 \\
\hline $\begin{array}{c}\text { Panties, petticoat, stockings, } \\
\text { dress, shoes }\end{array}$ & 0,7 & 0,105 \\
\hline $\begin{array}{c}\text { Underwear, shirt, trousers, } \\
\text { socks, shoes }\end{array}$ & 0,7 & 0,110 \\
\hline $\begin{array}{c}\text { Panties, shirt, trousers, jacket, } \\
\text { socks, shoes }\end{array}$ & 1,0 & 0,155 \\
\hline $\begin{array}{c}\text { Panties, stockings, blouse, } \\
\text { long skirt, jacket, shoes }\end{array}$ & 1,10 & 0,170 \\
\hline $\begin{array}{c}\text { Underwear with long sleeves } \\
\text { and legs, shirt, trousers, V- } \\
\text { neck sweater, jacket, socks, } \\
\text { shoes }\end{array}$ & 1,30 & 0,200 \\
\hline $\begin{array}{c}\text { Underwear with short sleeves } \\
\text { and legs, shirt, trousers, vest, } \\
\text { jacket, coat, } \\
\text { socks, shoes }\end{array}$ & 1,50 & 0,230 \\
\hline
\end{tabular}

Apart from the thermal balance condition the thermal comfort sensation means that a given person is not exposed to draughts or excessive air dryness or humidity. Such a perspective combined with the other parameters proves that thermal comfort is a subjective matter which depends on a given person's needs and preferences as well as on his/her clothes and the work he/she does. Therefore, it is impossible to formulate a universal set of parameters mentioned above that could be a guarantee of thermal comfort for everybody. However, an analysis may be conducted to determine such parameter values that will be satisfying for the greatest possible number of tested individuals.

Danish scientist Ole Fanger was the first to do research in this field. His extensive theoretical analysis, the proposed computational algorithms and the experimental verification are presented e.g. in $[17,18]$.

Fanger distinguished the following parameters affecting the global sensation of thermal comfort:

- Environmental parameters, unrelated to a given person directly:

- air temperature $t_{\mathrm{i}}$

- average (radiant) temperature of partitions $t_{\mathrm{pr}}$

- relative humidity of indoor air $\varphi_{1}$

- relative air velocity $v_{\mathrm{ar}}$

- Parameters related to a given person directly:

- clothing heat resistance clo

- a person's metabolic rate met

- age, sex, ethnic and geographical factors, nutrition habits, meal frequency, etc.

He gathered all these factors in two parameters being the basis of thermal comfort evaluation:

- the $P M V$ (predicted mean vote) index. This parameter provides information about the mean rating of a given thermal environment given by the assessing group. It relates to a thermally moderate environment. 
- the $P P D$ (predicted percentage dissatisfied) index. This parameter represents the percentage of people dissatisfied with thermal conditions they are exposed to in a given environment.

Fanger's works became the basis for European and international standards concerning thermal comfort and they were used to determine its criterial parameters, for example - the EN ISO 7730:2006 Standard. This standard, which is currently the basic normative act concerning the methods of evaluation of thermal comfort of rooms with a moderate microclimate, defines the methods of calculating and determining the $P M V$ and $P P D$ parameters both for steady-state conditions and for conditions varying in time. Moreover, it specifies categories that indoor environments are classified into based on variations in a series of thermal comfort parameters, additionally including quantities related to local thermal comfort conditions. These additional parameters are as follows:

- Draught rate $D R$. This parameter, expressed in percentages, informs about the draught exposure risk. It therefore represents the risk of local convective cooling.

- Vertical air temperature difference. This parameter provides information on thermal discomfort resulting from a difference in temperature between the head and ankles, for the case where an upward drop in temperature occurs.

- Warm and cool floors. This parameter informs about dissatisfaction with the floor temperature if light home shoes are worn.

- Radiant asymmetry. This parameter provides information about thermal discomfort caused by the partition temperature asymmetry, i.e. by differences in the temperatures of individual partitions (walls and ceilings).

For these parameters the $P D$ (percentage dissatisfied) index is defined, which informs about the percentage of people dissatisfied with given conditions. The room categories specified in the standard and the values of thermal comfort parameters required for them are listed in Table 3.

Tab. 3. Room categories related to values of thermal comfort parameters [15]

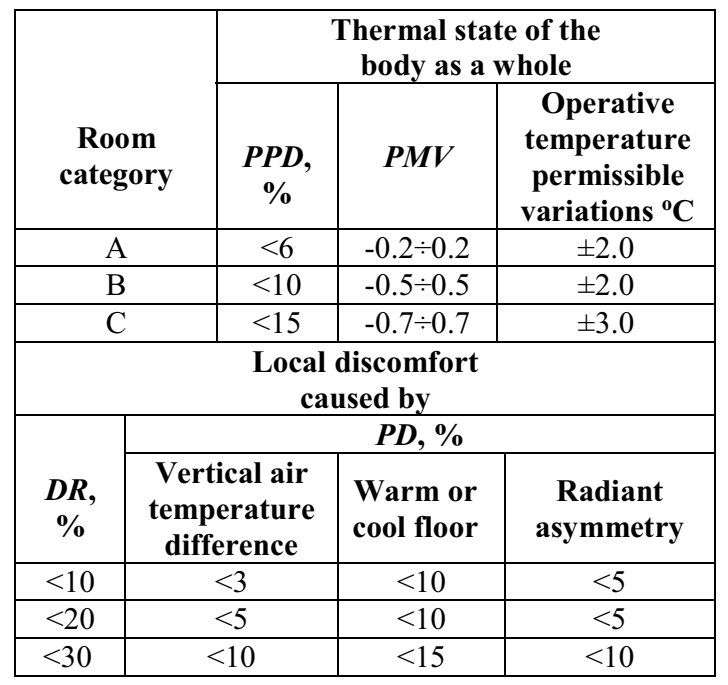

In addition to that, the permissible range of the floor temperature $\left(19 \div 29^{\circ} \mathrm{C}\right.$ for Category $\mathrm{A}$ and Category B), the maximum vertical gradient of temperature and other parameters are defined for the categories.

The $P M V$ index may be used if the following requirements are satisfied [15]:

- air temperature in the room under analysis: $10-30^{\circ} \mathrm{C}$,

- average radiant temperature of partitions in the room: $10-40^{\circ} \mathrm{C}$,

- air velocity in the room: $0-1 \mathrm{~m} / \mathrm{s}$,

- water vapour partial pressure in the room: 0-2700 Pa.

- metabolic rate of people in a given room: 0.8-4.0 met $\left(46.6-232.8 \mathrm{~W} / \mathrm{m}^{2}\right)$,

- a given person's clothing heat resistance: 0-2 clo.

This parameter is given on a seven-point scale of the thermal sensation:

- $(+3)$ hot

- $(+2)$ warm

$\bullet(+1)$ slightly warm

-(0) neutral

-(-1) slightly cool

-(-2) cool

$\cdot(-3)$ cold

An environment where $-2<P M V<2$ is considered as moderate. In respect of the foregoing, the following equation is right [15]:

$P M V=[(0,303 \cdot \exp (-0,036 \cdot \dot{M})+0,028)] \cdot\left\{(\dot{M}-\dot{W})_{-}\right.$

$0,00305 \cdot\left[\left(5733-6,99 \cdot(\dot{M}-\dot{W})-p_{\mathrm{a}}\right)\right]-0,42$.

$[(\dot{M}-\dot{W})-58,15]-0,000017 \cdot \dot{M} \cdot\left(5867-p_{\mathrm{a}}\right)-$

$0,0014 \cdot \dot{M} \cdot\left(34-t_{\mathrm{k}}\right)-3,96 \cdot 10^{-8} \cdot f_{\mathrm{cl}}$.

$\left.\left[\left(t_{\mathrm{cl}}+273\right)^{4}-\left(\bar{t}_{\mathrm{pr}}+273\right)^{4}\right]-f_{\mathrm{cl}} \cdot \alpha_{\mathrm{k}} \cdot\left(t_{\mathrm{cl}}-t_{\mathrm{k}}\right)\right\}$

where:

$$
\begin{aligned}
& t_{\mathrm{cl}}=35,7-0,028 \cdot(\dot{M}-\dot{W})-R_{\mathrm{cl}} . \\
& \left\{3,96 \cdot 10^{-8} \cdot f_{\mathrm{cl}} \cdot\left[\left(t_{\mathrm{cl}}+273\right)^{4}-\left(\bar{t}_{\mathrm{pr}}+273\right)^{4}\right]+\right. \\
& \left.+f_{\mathrm{cl}} \cdot \alpha_{\mathrm{k}} \cdot\left(t_{\mathrm{cl}}-t_{\mathrm{k}}\right)\right\}
\end{aligned}
$$

$\alpha_{\mathrm{k}}=\left\{\begin{array}{ll}2,38 \cdot\left|t_{\mathrm{cl}}-t_{\mathrm{k}}\right|^{0,25} & \text { for } 2,38 \cdot\left|t_{\mathrm{cl}}-t_{\mathrm{k}}\right|^{0,25}>12,1 \cdot \sqrt{v_{\mathrm{ar}}} \\ 12,1 \cdot \sqrt{v_{\mathrm{ar}}} & \text { for } 2,38 \cdot\left|t_{\mathrm{cl}}-t_{\mathrm{k}}\right|^{0,25}<12,1 \cdot \sqrt{v_{\mathrm{ar}}}\end{array}\right\}$

$$
f_{\mathrm{cl}}=\left\{\begin{array}{l}
1,0+1,290 \cdot R_{\mathrm{cl}} \text { for } R_{\mathrm{cl}} \leq 0,078\left(\mathrm{~m}^{2} \mathrm{~K}\right) / \mathrm{W} \\
1,05+0,645 \cdot R_{c l} \text { for } R_{\mathrm{cl}}>0,078\left(\mathrm{~m}^{2} \mathrm{~K}\right) / \mathrm{W}
\end{array}\right\}
$$

According to the following formula, a certain value of the $P P D$ parameter may be assigned to a given value of the $P M V$ index [15]: 
$P P D=100-95 \cdot \exp \left(-0,03353 \cdot P M V^{4}-0,2179 \cdot P M V^{2}\right)$

It is obvious that the farther the $P M V$ value is from zero, the higher the number of people dissatisfied with thermal comfort of a given environment will be, i.e. the value of the $P P D$ parameter will be higher. The relation between the two quantities is presented graphically in Fig. 1. It can be seen that at the average rating at the level of $P M V=0$, the predicted percentage of dissatisfied people is the lowest and totals $P P D=5 \%$. This also means that irrespective of the conditions of a given room environment, if the number of evaluating people is sufficiently high, there will always be individuals with a thermal discomfort sensation. In order to achieve thermal comfort, it is recommended that $-0.5<P M V<0.5$. Then $P P D=10 \%$.

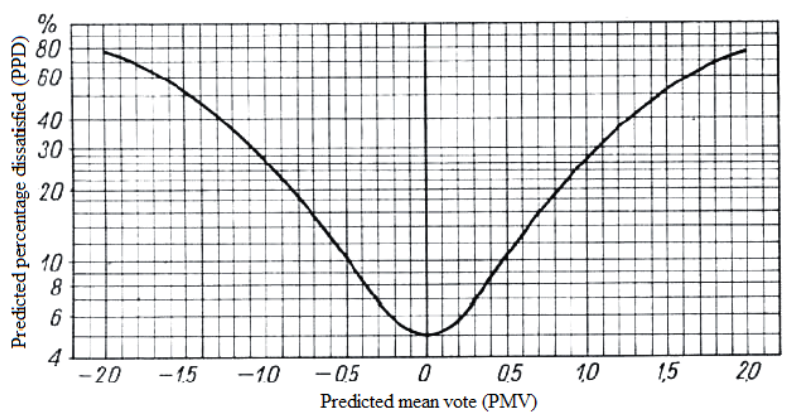

Fig. 1. Relation between PMV and PPD parameters [17, 18, 15]

Fanger carried out a comprehensive study aiming to determine the impact of thermal comfort individual components, and combinations thereof, on the $P M V$ and $P P D$ parameters. For habitable and office rooms some parameter values may be assumed at a certain level. Owing to that and based on the expected $P M V$ value as close to zero as possible, the required values of the air temperature as well as of radiant and operative temperatures may be found by means of the formulae mentioned above. It is also possible to use charts made based on these relations. The charts plotted for selected values of the required parameters are presented in Fig. 2.
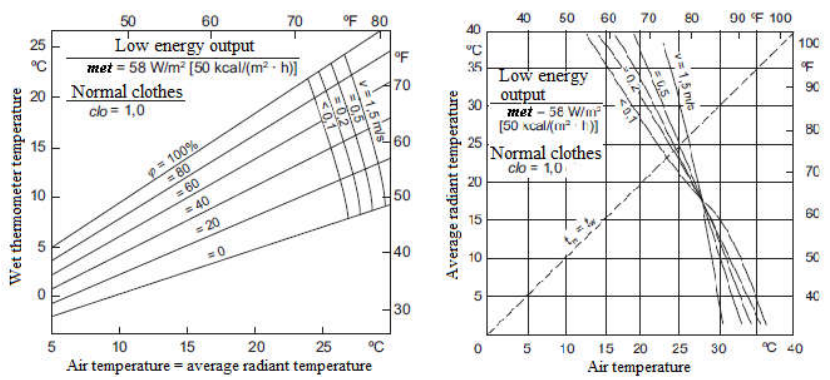

Fig. 2. Charts illustrating changes in thermal comfort for selected cases $[17,18]$

Assuming the following typical values for a sitting person resting at home of $c l o=1.0$, met $=1.0\left(58 \mathrm{~W} / \mathrm{m}^{2}\right)$, $v_{\text {ar }}<0.1 \mathrm{~m} / \mathrm{s}, \varphi_{1}=50 \%$, the optimum operative temperature (i.e. one at which $P M V=0$ ) is obtained at the level of about $23^{\circ} \mathrm{C}$. For the same conditions in the case of typical office work $(m e t=1.1 \div 1.2)$ the value amounts to approximately $22^{\circ} \mathrm{C}$.

As indicated by Formula (1), the optimum operative temperature may be achieved by different combinations of the air temperature and radiation. For instance, raising the radiant temperature of partitions, the air temperature may be reduced and vice versa. However, it should be remembered that too big an asymmetry of the air or radiant temperatures will make it impossible to achieve the optimum $P M V$ value even if the resultant operative temperature equals the required value. According to Table 1 and assuming the room Category B with $-0.5<P M V<0.5$ as the reference point, the permissible variations in the operative temperature are included in the range of $\pm 2.0^{\circ} \mathrm{C}$ compared to the required temperature level, which is conditioned by the clo, met, $w$ and $\varphi_{1}$ parameters. For the previous level of these parameters, i.e. $c l o=1.0$, met $=1.2, v_{\mathrm{ar}}<0.1 \mathrm{~m} / \mathrm{s}$ and $\varphi_{1}=50 \%$, the optimum operative temperature is $22^{\circ} \mathrm{C}$. Considering the assumed thermal category of the room, the permissible operative temperature value is thus included in the range of $20 \div 24^{\circ} \mathrm{C}$. Knowing the permissible range of the operative temperature variability, a set of permissible variations in the air and radiant temperatures may be established according to Formula (1). As stated above, if it is assumed that the difference between individual temperatures is smaller than $4^{\circ} \mathrm{C}$, then an assumption may also be made of the equality of individual components of the surface film conductance coefficients in the formula. The range of permissible temperatures will then be as presented in Fig. 3.

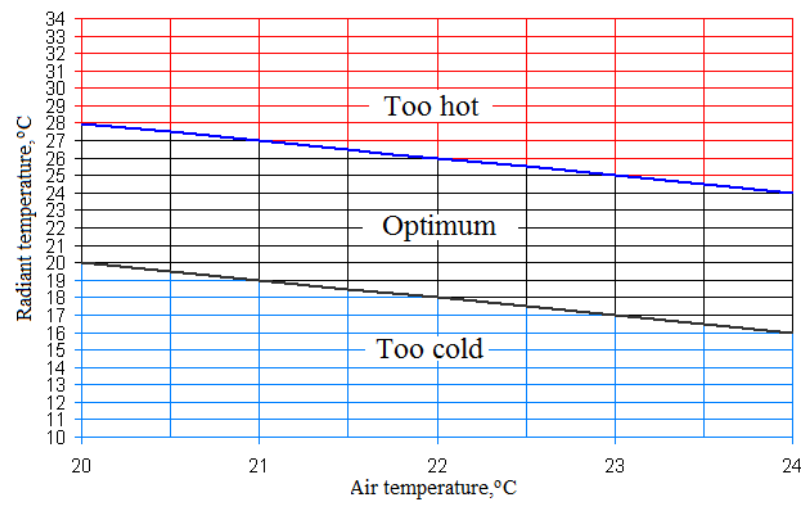

Fig. 3. Optimum (permissible) temperature range

In practice, calculations of thermal comfort conditions using the $P M V$ and SET indices give similar results.

Knowledge of the unit thermal power (energy output) emitted by the human body, referred to the $1 \mathrm{~m}^{2}$ of the skin is needed to determine the thermal comfort parameters. It may also be an important component of the overall heat balance of the room, conditioning the size of the radiator. To determine it, it is needed not only a knowledge of the number of people staying in the room and emitted unit thermal power, but also the surface of the skin of the human body. There are many alternative formulae to calculate this parameter. One of the most frequently used is the DuBois formula [21]: 


$$
A_{s}=0,20248 \cdot m_{c z}^{0,425} \cdot h_{c z}^{0,725}
$$

It applies to adults. For a male of an average body structure the formula results with a value of $A_{\mathrm{s}}=1.9 \mathrm{~m}^{2}$, and for female $A_{\mathrm{s}}=1.6 \mathrm{~m}^{2}$. It follows that, for example, for a male in a sitting position who is not performing any physical work, the value of the emitted thermal power is $A_{\mathrm{s}} \cdot 1 \mathrm{met}=1.9 \mathrm{~m}^{2} \cdot 58 \mathrm{~W} / \mathrm{m}^{2}=110 \mathrm{~W}$.

Based on unit thermal power emitted by the human body in the metabolism process and because of the physical work performed, it is also calculated the daily caloric need. It is assumed that a daily average value of this parameter for a typical male $\left(A_{\mathrm{s}}=1.9 \mathrm{~m}^{2}\right)$ with a standard physical activity is approx. $2500 \mathrm{kcal}$, which gives approx. $10,500 \mathrm{~kJ}=10500 \mathrm{kWs}$. This results with a unit thermal power at a level of 10500000/24 (hours per day)/60 (minutes in an hour) $/ 60$ (seconds in a minute) $/ 1.9 \mathrm{~m}^{2}$ (skin surface) $=64 \mathrm{~W} / \mathrm{m}^{2}$. This is a typical daily average unit thermal power emitted.

\section{Polish legal requirements regarding the temperatures in a residential environments in relation to the conditions of thermal comfort}

Currently the main Polish legislative act defining the temperature values that must be preserved in a residential environments, is quoted earlier document [2]. The selected requirements contained in it, taken with minor changes from the archive Polish Standard PN82/B-02402P [22], are presented in Table 4.

Tab. 4. The required temperatures in a residential environments [2]

\begin{tabular}{|c|c|c|}
\hline $\begin{array}{l}\text { Design } \\
\text { temp.* }\end{array}$ & $\begin{array}{c}\text { Purpose or use of the } \\
\text { premises }\end{array}$ & Exemplary rooms \\
\hline$+20^{\circ} \mathrm{C}$ & $\begin{array}{l}\text { - intended for a permanent } \\
\text { human occupancy without } \\
\text { outerwear, not performing } \\
\text { out a continuous physical } \\
\text { labor }\end{array}$ & $\begin{array}{l}\text { living rooms, hallways, } \\
\text { kitchens equipped with } \\
\text { individual gas or } \\
\text { electric } \\
\text { furnaces, office rooms, } \\
\text { meeting rooms }\end{array}$ \\
\hline$+24^{\circ} \mathrm{C}$ & $\begin{array}{l}\text { - intended to undressing, } \\
\text { - intended to accommodate } \\
\text { people without clothing }\end{array}$ & $\begin{array}{l}\text { bathrooms, changing } \\
\text { rooms, washrooms, } \\
\text { shower halls, } \\
\text { swimming offices } \\
\text { medical fools, } \\
\text { intended for patients } \\
\text { undressing, infants and } \\
\text { meeting rooms for } \\
\text { children in nurseries, } \\
\text { surgery rooms }\end{array}$ \\
\hline \multicolumn{3}{|c|}{$\begin{array}{l}\text { *) It is allowed to take other design temperatures for the heatec } \\
\text { rooms than specified in the table, if this is due to the } \\
\text { technological requirements. }\end{array}$} \\
\hline
\end{tabular}

This standard also indicates the need to consider the influence of radiation temperature felt by humans. It is given therein that:

"Indoor temperature $t_{\mathrm{ix}}$ in residential and office buildings should be in ${ }^{\circ} \mathrm{C}$ :
- when using convection radiators (panel radiators, column radiators, etc)

- if there is one cooling partition $t_{\mathrm{ix}}=t_{\mathrm{i}}$

- if there are two cooling partitions $t_{\mathrm{ix}}=t_{\mathrm{i}}+1$

- if there are three cooling partitions $t_{\mathrm{ix}}=t_{\mathrm{i}}+2$

- if there are four cooling partitions $t_{\mathrm{ix}}=t_{\mathrm{i}}+3$

- when using surface radiators (floor radiators, wall radiators, ceiling radiators) $t_{\mathrm{ix}}=t_{\mathrm{i}}-1 "$

Unfortunately, in the current legislation [2] these recommendations have been omitted.

The optimum temperature ranges are also given in the archival Polich Standard PN-B-03421:1978 [23]. The standard defines parameters for three cases:

- Low metabolic rate (e.g. sewing, bookkeeping, typewriting):

- indoor room temperature of air in winter: $20-22^{\circ} \mathrm{C}$; in summer: $23-26^{\circ} \mathrm{C}$,

- relative humidity (irrespective of physical activity) in winter: $40-60 \%$; in summer: $40-55 \%$,

- air velocity in winter: up to $0.2 \mathrm{~m} / \mathrm{s}$; in summer: up to $0.3 \mathrm{~m} / \mathrm{s}$.

- Medium metabolic rate (e.g. nail driving, plastering):

- indoor room temperature of air in winter: $18-20^{\circ} \mathrm{C}$; in summer: $20-23^{\circ} \mathrm{C}$,

- relative humidity in summer: $40-60 \%$,

- air velocity in winter: up to $0.2 \mathrm{~m} / \mathrm{s}$; in summer: up to $0.4 \mathrm{~m} / \mathrm{s}$.

- High metabolic rate (e.g. carrying heavy objects):

- indoor room temperature of air in winter: $15-18^{\circ} \mathrm{C}$; in summer: $18-21^{\circ} \mathrm{C}$,

- relative humidity in summer: $40-60 \%$,

- air velocity in winter: up to $0.3 \mathrm{~m} / \mathrm{s}$; in summer: up to $0.6 \mathrm{~m} / \mathrm{s}$.

In practice most often taken into account are temperatures values $20^{\circ} \mathrm{C}$ and $24^{\circ} \mathrm{C}$, correct for rooms, living rooms, bedrooms, kitchens and bathrooms. Such temperatures are adopted in practice by the designers, architects and installers, both in the calculation of the design thermal heat load of the building and its various rooms, and in the case of designing of the heating system, for determining the operating temperature of system components, the size, power, and type of boiler, type and size heaters, valves settings, pipe diameters, etc. Over the years, Polish legal requirements regarding the indoor temperatures were changing. These data were given in previous versions of the Polish Standard PN82/B-02402P [22] (with the status of mandatory for use at that time). A significant change, resulting in a requirement to ensure higher indoor temperatures than was the case in previous years, was introduced in the Polish Standard in 1974. This was due to the publication of the Fanger work $[17,18]$ and conclusions, which he formulated. The values of this parameter for earlier versions of this standard are summarized in Table 5 . 
Tab. 5. Indoor temperatures in the winter time - Polish normative requirements

\begin{tabular}{|c|c|c|c|c|c|}
\hline \multirow{2}{*}{$\begin{array}{l}\text { Type of the } \\
\text { room }\end{array}$} & \multicolumn{4}{|c|}{ Number of the standard/year } & \multirow{2}{*}{$\begin{array}{l}\text { Temp. } \\
{ }^{\circ} \mathrm{C}\end{array}$} \\
\hline & $1^{*}$ & $2^{*}$ & $3^{*}$ & $4^{*}$ & \\
\hline $\begin{array}{l}\text { Living rooms, } \\
\text { hallways }\end{array}$ & 18 & 18 & 18 & 20 & 20 \\
\hline Kitchens & 15 & 15 & 15 & 20 & 20 \\
\hline Bathrooms & 22 & 22 & 22 & 24 & 24 \\
\hline
\end{tabular}

$1^{*}$ ) PN-B-02402:1954; 2*) PN-B-02402:1959;

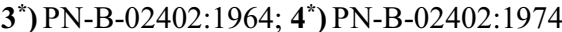

It is thus seen that in all the Polish recommendations and legal standards, recommended temperatures do not correspond with optimal temperatures of thermal comfort and are lower. In addition, these records do not distinguish between an operative temperature, the air temperature and the radiation temperature, and usually refer to the temperature of air. Most often the operative temperature is lower than air temperature due to the occurrence of cooling partitions (windows, exterior walls - product of the heat transfer surface and the temperature prevails over the product of the heating elements). Differences, if you take into account the subjective feelings of the people staying in the given conditions, can be significant. If, for example, calculate the values of $P M V$ and $P P D$ using formulas (3) and (7) for a room intended for permanent people occupancy, who do not perform any continuous physical labor, in normal clothing in winter $\left(c l o=1,0\right.$, met $=1,0, v_{\mathrm{ar}}<0,1 \mathrm{~m} / \mathrm{s}$ i $\left.\varphi_{1}=50 \%\right)$, for which, according to Polish law required temperature should be at the level of $t_{\mathrm{i}}=20^{\circ} \mathrm{C}$ (assuming that the air temperature is equal to the radiation temperature), it turns out that ir results with the values $P M V=-0,85$ and $P P D=20.25 \%$. In addition, as shown in Table 3, that temperature value means that room should be classified to the lowest category (category $\mathrm{C}$ ) from the point of view of providing thermal comfort. In fact, in practice, often users tend to obtain higher temperatures, the value of $t_{i}=20^{\circ} \mathrm{C}$ is in fact perceived as far too low for a large percentage of the respondents.

\section{Conclusions}

Assuming in the design process and operation of the heating system temperatures compatible with Polish legal requirements, not complying with the optimal conditions of thermal comfort, can have several effects:

- Ergonomic:

- reduced thermal comfort category of the room

- increased percentage of people dissatisfied with the conditions of the microclimate and the thermal comfort of the room

- the need for additional clothing

- Economic:

- reduction of investment costs of installation. A lower temperature results in a lower design thermal load of the building and, therefore, lower power demand for the heat source (eg. a boiler) and radiators. This lowers the purchase price of these devices.
- reduce the operating costs of installation. The requirement to provide smaller heat power to the object can reduce fuel costs, as well as electricity costs for driving the circulation pump.

In both cases of the economic aspects, the differences are conditioned both with the a particular climate zone to which the building belongs, as well as the price of equipment. The lower external design and average yearround temperature (during the heating season) adopted for the calculation, the greater the differences. Design temperature affects primarily on the investment costs, because it affects the size and cost of the devices. The average year-round temperature in the heating season has an impact primarily on the operating costs, because it affects the amount of fuel consumed and energy use. These costs are approximately proportional to the design temperatures difference - external and internal. For example, for climatic zone III (intermediate zone in Poland) and the location of Krakow, for which the design temperature is $t_{\mathrm{e}}=-20^{\circ} \mathrm{C}$, and the average temperature during the heating season is $t_{\mathrm{em}}=3,12^{\circ} \mathrm{C}$ (calculated in accordance with meteorological data contained in the archive Polish PN-B-02025:2001P [24]), an increase of design temperature from $t_{\mathrm{i}}=20^{\circ} \mathrm{C}$ to $t_{\mathrm{i}}=23^{\circ} \mathrm{C}$ results in an increase in operating costs at the level of $\{[(23-3,12)-(20-3,12)] /(20-3,12)\} \cdot 100 \%=17,8 \%$. The increase of the design thermal load is at the level of $\{[(23-(-20))-(20-(-20))] /(20-(-20)\} \cdot 100 \%=7.5 \%$. The actual difference in the cost will naturally depend on the the current weather conditions and the actual average temperature during the heating season for a given year. it can be seen, also in Poland, that the climatic conditions in recent years have changed significantly. The average year-round temperature and the minimum, design temperature, increased. This fact, however, is not included in Polish legal requirements related to the climate zones and design temperatures. With the increase of the design and the year-round average temperature during the heating season also increase differences in investment and operating costs when assuming a higher indoor temperature. But this is not an important argument against the adoption of higher indoor temperatures, because at the same time decreasing then both operating and investment costs for a given indoor temperature - higher external temperatures, in a natural way, decrease heating costs.

\section{Symbols list}

$A_{\mathrm{s}}$ - the surface area of the skin, $\mathrm{m}^{2}$,

$\alpha_{\mathrm{k}}$ - convection term of the surface film conductance (convective heat transfer coefficient), $\mathrm{W} /\left(\mathrm{m}^{2} \cdot \mathrm{K}\right)$,

$\alpha_{\mathrm{pr}}$-radiation term of surface film conductance (radiative heat transfer coefficient), $\mathrm{W} /\left(\mathrm{m}^{2} \cdot \mathrm{K}\right)$,

$f_{\mathrm{cl}}$ - clothing surface area factor, -,

$\varphi_{\mathrm{i}}$ - relative humidity of indoor air, -, $\%$,

$h_{\mathrm{cz}}$ - the human's height, m,

$\dot{M}$ - unit heat output generated due to metabolism, $\mathrm{W} / \mathrm{m}^{2}$,

$m_{\mathrm{cz}}-$ body mass, $\mathrm{kg}$,

$p_{\mathrm{a}}-$ water vapour partial pressure, $\mathrm{Pa}$, 
$R_{\mathrm{cl}}-$ clothing insulation, $\left(\mathrm{m}^{2} \cdot \mathrm{K}\right) / \mathrm{W}$,

$t_{\mathrm{cl}}-$ clothing surface temperature, ${ }^{\circ} \mathrm{C}$,

$t_{\mathrm{e}}-$ design temperature of the outdoor (surrounding) air,

${ }^{\circ} \mathrm{C}$,

$t_{\mathrm{em}}-$ year-round average temperature of the outdoor (surrounding) air, ${ }^{\circ} \mathrm{C}$,

$t_{\mathrm{i}}-$ conventional temperature of the indoor (surrounding) air, ${ }^{\circ} \mathrm{C}$,

$t_{\mathrm{k}}$ - convection temperature (air), ${ }^{\circ} \mathrm{C}$,

$t_{\text {oper }}-$ operative temperature, ${ }^{\circ} \mathrm{C}$,

$t_{\mathrm{pr}}$ - radiant temperature (partitions and elements of fittings), ${ }^{\circ} \mathrm{C}$,

$\dot{q}_{\text {ak,sk }}$ - unit heat output accumulated in skin, $\mathrm{W} / \mathrm{m}^{2}$,

$\dot{q}_{\text {ak,org }}$ - unit heat output accumulated inside the organism, $\mathrm{W} / \mathrm{m}^{2}$,

$\dot{q}_{\text {konw }}$ - unit heat output given up to the surroundings through convection, $\mathrm{W} / \mathrm{m}^{2}$,

$\dot{q}_{\mathrm{pr}}$ - unit heat output given up to the surroundings through radiation, $\mathrm{W} / \mathrm{m}^{2}$,

$\dot{q}_{\text {pot }}$ - unit heat output given up to the surroundings to evaporate sweat from the skin (latent heat), $\mathrm{W} / \mathrm{m}^{2}$,

$\dot{q}_{\text {odd.konw }}$ - unit heat output given up to the surroundings due to breathing, by means of convection, $\mathrm{W} / \mathrm{m}^{2}$,

$\dot{q}_{\text {odd.par }}$ - unit heat output given up to the environment due to breathing, by means of evaporation, $\mathrm{W} / \mathrm{m}^{2}$, $v_{\text {ar }}$ - relative air velocity, $\mathrm{m} / \mathrm{s}$,

$\dot{W}$ - unit heat output converted to mechanical work, $\mathrm{W} / \mathrm{m}^{2}$,

\section{References}

1. Construction Law of 7 July 1994, Dz.U. (Journal of Laws) 94.89.414, as amended (in Polish: Prawo budowlane z dnia 7 lipca 1994 r., Dz.U. Nr 89, poz. 414, z późn. zm.),

2. Regulation of the Minister of Infrastructure of 12 April 2002 on the technical conditions to be met by buildings and their location, Dz.U. (Journal of Laws) 02.75.690 as amended (in Polish: Rozporządzenie Ministra Infrastruktury z dnia 12 kwietnia 2002 roku w sprawie warunków technicznych, jakim powinny odpowiadać budynki i ich usytuowanie, Dz.U.02.75.690 z późniejszymi zmianami),

3. T. Bedford, Basic principles of ventilation and heating, Lewis, London, (1948),

4. F.C. Houghten, C.P. Yaglou, Determining lines of equal comfort, ASHVE Trans., pp. 163-176 and 361-384, 28 (1923),

5. A.P. Gagge, J.A.J. Stolwijk, Y. Nishi, An effective temperature scale, based on a simple model of human physiological regulatory response, ASHRAE trans.: pp. 247-262, 77 (1971),

6. P. Gagge, Y. Nishi, Effective temperature scale useful for hypo and hyperbaric environments, Aviation, Space, and Environmental Medicine, pp. 97-107, February, 48 nr.2, (1977),
7. R.R. Gonzalez, Y. Nishi, A.P. Gagge, Experimental Evaluation of Standard Effective Temperature. A New Biometeorological Index of Man's Thermal Discomfort, International Journal of biometeorology, pp.1-15, 18 (1974),

8. K. Cena, J.A. Clark, Studies in Environmental Science. Bioengineering, Thermal physiology and comfort, Elsevier, (1981),

9. American Standard ASHRAE standard 55-2013: Thermal Environmental Conditions for Human Occupancy,

10. A.R. Chandra, Refrigeration and Air Conditioning”, PHI Learning Private Limited, New Delhi, (2010),

11. A.P. Gagge, J. Nishi, R.R. Gonzales, Standard Effective Temperature, Symposium Thermal Comfort and Moderate Heat Stress, CIB Commission W45, Building Research Establishment, (1972),

12. W.P. Jones, Air Conditioning Engineering (fifth edition), Elsevier Butterworth Heinemann, (2001),

13. B. Nowakowski, Principles of ventilation and heating of working places (In Pplish: Zasady wietrzenia i ogrzewania zakładów pracy), Instytut Spraw Społecznych, Warsaw (1935),

14. International Standard ISO 7726:2002: Ergonomics of the thermal environment. Instruments for measuring physical quantities,

15. International Standard ISO 7730:2005: Ergonomics of the thermal environment -- Analytical determination and interpretation of thermal comfort using calculation of the PMV and PPD indices and local thermal comfort criteria,

16. Z. Kabza, Parameter and thermal power engineering equipment measurements (in Polish: Pomiary parametrów i urządzeń termoenergetycznych), a report prepared within the project "The Czestochowa University of Technology Development Plan" co-financed from the EU funds under the European Social Fund (Project No POKL. 04.01.01-00-059/08),

17. P.O. Fanger, Thermal comfort (In Polish: Komfort cieplny), Arkady, Warsaw, (1974),

18. P.O. Fanger, Thermal Comfort. Analysis and Applications in Environmental Enginnering, Danish Technical Press, Copenhagen, (1970),

19. World Wide Web of Centralny Instytut Ochrony Pracy CIOP: www.ciop.pl.

20. A.P. Gagge, A.C. Burton, H.C. Bazett, A practical system of unit for the description of heat exchange of man with his environment, Science, pp. 428-430, 94 (1941).

21. D. Du Bois, E.F. Du Bois, A formula to estimate the approximate surface area if height and weight be known, Archives of Internal Medicine, pp. 863-871, 17 (1916),

22. Polish Standard PN-82/B-02402P: Heating - Indoor temperatures in buildings (in Polish: Ogrzewnictwo - Temperatury ogrzewanych pomieszczeń w budynkach),

23. Polish Standard PN-B-03421:1978P: Ventilation and air-conditioning. Calculation parameters of indoor air in rooms intended for permanent 
occupation by humans (in Polish: Wentylacja i klimatyzacja. Parametry obliczeniowe powietrza wewnętrznego $\mathrm{w}$ pomieszczeniach przeznaczonych do stałego przebywania ludzi),

24. Polish Standard PN-B-02025:2001P: The calculation of seasonal heat demand for heating of residential buildings (in Polish: Obliczanie sezonowego zapotrzebowania na ciepło do ogrzewania budynków mieszkalnych i zamieszkania zbiorowego). 